\title{
HUMAN-COMPUTER INTERACTION (HCI) \\ DAN IMPLIKASINYA TERHADAP PERUBAHAN POLA KOMUNIKASI KELUARGA
}

\author{
Ika Rusdiana \\ IAIN Ponorogo \\ rosdyana.ika@iainponorogo.ac.id
}

\begin{abstract}
Communication has a very important role in human life, so that it is stated "communication is the essence of human life", this statement confirms that without effective communication, human survival will be disrupted, even in the context of family life, it will have the potential to cause dysfunction in the system. family. The phenomenon that occurs in modern family life today, which is marked by the presence of information technology, is allegedly one of the factors causing the shift in family communication systems and patterns, namely from face-toface conventional patterns to modern patterns through online media. The family communication pattern is a framework that emphasizes the way individuals interact with one another. Thus, it cannot be denied that human interaction with technology has formed a new rhythm in the daily life of the family, namely an increasingly complex rhythm of interaction, which is not only "real" interaction, but also "virtual" interaction. This study tries to explain how the implications of human-computer interaction on changes in family communication patterns in Ponorogo district. With a qualitative approach, it was found that the intensity of interaction between humans and technology has reduced the elements in the functioning of the family system, namely: 1) interdependence; 2) wholeness; 3) pattern/self-regulation; 4) interactive complexity; 5) Openness; 6) Complex relationships; 7) Equality (Equifinality). In family communication patterns, these elements also determine changes in family communication patterns consisting of conversational dimensions and conformity dimensions. On the conversational dimension, to a certain extent, families in Ponorogo Regency showed a decrease in interest in discussing certain topics/problems within the family, and even tended to feel uncomfortable in conveying various personal information. This condition is related to the increase in the second dimension, namely the conformity dimension. On the dimension of conformity (conformity), family members; both children and parents, often show an expressive attitude that shows disagreements with other family members. In the context of family communication patterns, the increasing dimension of conformity has the potential to cause family conflict, because each family member puts forward his individuality based on the suitability he believes in.
\end{abstract}

Keyword: Human-Computer Interaction, Family Communications patterns.

ABSTRAK: Komunikasi memiliki peran yang sangat penting bagi kehidupan manusia, sehingga dinyatakan "communication is the essence of human Life", pernyataan ini menegaskan bahwa tanpa komunikasi yang efektif, keberlangsungan hidup manusia akan terganggu, bahkan dalam konteks kehidupan keluarga, akan sangat berpotensi memunculkan disfungsi pada sistem keluarga. Fenomena yang terjadi pada kehidupan keluarga modern saat ini, yang ditandai dengan hadirnya teknologi informasi, disinyalir merupakan salah satu faktor penyebab bergesernya sistem dan pola komunikasi keluarga, yakni dari pola konvensional tatap muka ke pola modern 
melalui media online. Pola komunikasi keluarga merupakan satu kerangkan kerja yang menekankan pada cara individu dalam berinteraksi satu sama lain. Dengan demikian, tidak dapat dipungkiri bahwa interaksi manusia dengan teknologi telah membentuk satu ritme baru dalam kehidupan sehari-hari keluarga, yakni ritme interaksi yang semakin kompleks, yang tidak hanya interaksi secara "nyata", tetapi juga interaksi secara "maya". Penelitian ini mencoba menjelaskan bagaimana implikasi human-computer interaction terhadap perubahan pola komunikasi keluarga di kabupaten ponorogo. Dengan pendekatan kualitatif, ditemukan bahwa intensitas interaksi antara manusia dan teknologi telah mereduksi unsur-unsur dalam keberfungsian sistem keluarga, yakni: 1) interdependensi; 2) wholeness; 3) pola/regulasi diri; 4) kompleksitas interaktif; 5) Openness; 6) Hubungan yang kompleks; 7) Kesamaan (Equifinality). Dalam pola komunikasi keluarga, unsur-unsur tersebut turut menentukan perubahakan pola komunikasi keluarga yang terdiri dari dimensi percakapan dan dimensi konformitas (kesesuaian). Pada dimensi percakapan, dalam kadar tertentu, keluarga di Kabupaten Ponorogo menunjukkan adanya penurunan minat dalam membicarakan topik/permasalahan tertentu dalam keluarga, bahkan cenderung muncul rasa kurang nyaman dalam menyampaikan berbagai informasi pribadi. Kondisi ini berkaitan dengan meningkatnya dimensi kedua, yakni dimensi kesesuaian (konformitas). Pada dimensi kesesuaian (konformitas), anggota keluarga; baik anak-anak maupun orang tua, kerap menunjukkan sikap ekspresif yang menunjukkan adanya ketidaksepahaman pemikiran dengan anggota keluarga yang lain. Dalam konteks pola komunikasi keluarga, meningkatnya dimensi konformitas cukup berpotensi dalam memunculkan konflik keluarga, karena masing-masing anggota keluarga mengedepankan sisi individualitasnya berdasarkan kesesuaian yang diyakininya.

Kata kunci: Human-Computer Interaction, Family Communications patterns.

\section{PENDAHULUAN}

Kajian tentang komunikasi keluarga selalu menjadi isu hangat di kalangan para peneliti dan akademisi, hal ini diantaranya disebabkan oleh pola-pola dalam komunikasi keluarga yang terus mengalami dinamika, tak terkecuali pada era sekarang ini, dimana kehidupan keluarga diwarnai dengan ragam media digital yang sangat canggih. Selama 30 tahun terakhir, para akademisi dan peneliti telah melakukan langkah besar (red. Meneliti dan mengkaji) dalam menciptakan satu pemahaman baru tentang bagaimana komunikasi dapat mempengaruhi interaksi dan relasi anggota keluarga, serta sangat berpengaruh terhadap kualitas hubungan keluarga.

Secara kodrati, manusia terlahir dengan membawa rasa ingin tahu yang tinggi, sehingga memaksanya untuk terus belajar dengan menjalin komunikasi antar sesamanya, disamping dalam rangka untuk mempertahankan dan memenuhi kebutuhan hidupnya. Dengan demikian, peran komunikasi sangatlah penting dan tidak dapat dipisahkan dari kehidupan manusia termasuk dalam kehidupan keluarga, bahkan dikatakan "communication is the essence of human life". ${ }^{1}$ Oleh karena komunikasi

1 Janice Light. "Communication is The Essence of Human Life". Journal of Augmentative and Alternative Communication, Vol 13, 1997, P. 62. 
merupakan esensi kemanusiaan, maka untuk mencapai tujuan tersebut individu dituntut untuk mengembangkan kompetensi komunikasi mereka guna mencapai keseimbangan dalam hidup. Secara definitif, komunikasi dapat dipahami sebagai kegiatan bersama yang sangat tergantung pada kemampuan individu untuk menjaga perhatian bersama, untuk berbagi pengetahuan dan pengalaman. ${ }^{2}$

Komunikasi keluarga berbeda dengan komunikasi antarkelompok biasa, setiap anggota keluarga memiliki pola komunikasi yang berbeda. Perbedaan ini dipengaruhi oleh beberapa factor, diantaranya adalah sikap orangtua yang berhubungan dengan afeksi dan dominasi. Kualitas komunikasi keluarga sangat menentukan keberfungsian keluarga, serta turut menentukan arah perkembangan keluarga menuju keluarga sehat dan Bahagia.

Berbicara tentang perubahan pola komunikasi keluarga, tentu tidak dapat dilepaskan dari kehadiran teknologi informasi dalam kehidupan sehari-hari. Kurang lebih 20 tahun setelah diperkenalkannya komputer secara komersil, perusahaan komputer mulai memikirkan aspek fisik dari antarmuka pengguna sebagai faktor penentu keberhasilan pemasaran produk, dan diperkenalkanlah komputer pribadi (PC), sehingga penggunaan teknologi ini menarik perhatian publik dalam berbagai bidang seperti pendidikan, perdagangan, pertahanan, dan sebagainya. ${ }^{3}$

Pada era digital sekarang ini, yang ditandai dengan adanya perubahan secara fundamental dalam cara kerja yang menitikberatkan pada pengelolaan data, sistem kerja dengan pemanfaatan teknologi, serta sistem komunikasi dalam interaksi manusia yang lebih efisien, telah menggeser pola-pola interaksi antarmanusia secara masif dan signifikan. ${ }^{4}$ Perubahan signifikan dalam sistem komunikasi ini ditandai dengan semakin canggihnya interaksi antara manusia dan komputer (IMK)/ HCI (Human-Computer Interaction). HCI dapat diartikan sebagai serangkaian proses, kegiatan, dialog yang dilakukan oleh manusia untuk berinteraksi dengan komputer yang keduanya saling memberikan masukan dan umpan balik melalui sebuah antarmuka untuk memperoleh hasil yang diharapkan. ${ }^{5}$

Human-Computer Interaction (HCI) atau Interaksi Manusia-Komputer memiliki cakupan atau fokus perhatian yang luas, tidak hanya berfokus pada rancangan antarmuka saja, tetapi juga memperhatikan semua aspek yang berhubungan dengan interaksi antara manusia dan komputer. HCI ini kemudian berkembang sebagai disiplin ilmu tersendiri (yang merupakan bidang ilmu interdisipliner) yang membahas

${ }^{2}$ Herbert H. Clark. Using Language. Cambridge: Cambridge University Press. 1996 P. 167

${ }^{3}$ Andikos Adi Fitra, komunikasi manusia dengan komputer, In Media, 2016, hal. 5.

${ }^{4}$ Quipper Campus, Tantangan Di Era Revolusi Industry 4.0 Bagi Perguruan Tinggi Di Indonesia. Diunduh dari https://www.quipper.com/id/blog/quipper-campus/campus-info/revolusi-industri4-0/ pada tanggal 01 Agustus 2018.

${ }^{5}$ Lucy A. Suchman. Plan and Situated Action; The Problem of Human-Machine Communication. NY, Cambridge: Cambridge University Press. 1999. P. 12. 
hubungan timbal balik antara manusia-komputer beserta efek-efek yang terjadi diantaranya. ${ }^{6}$

Beberapa hasil penelitian menunjukkan bahwa interaksi manusia dengan komputer telah merubah pola komunikasi dalam keluarga, baik komunikasi antara suami dan istri, maupun interaksi antara orang tua dengan anak. Prudential Relationship Index, dalam surveinya menemukan bahwa sepanjang tahun 2015 terdapat 7.522 kasus perceraian, dan $28 \%$ responden menyatakan penyebab perceraiannya adalah masalah pasangannya yang terus menerus berinteraksi dengan telepon genggam. ${ }^{7}$ Tidak hanya itu, Komisi Perlindungan Anak Daerah (KPAID) Kota Bekasi juga mencatat bahwa penggunaan gawai memicu kekerasan terhadap anak. Tercatat sampai Bulan Juli 2019 terdapat 47 kasus kekerasan terhadap anak (kekerasan psikis dan seksual). Secara psikologis, munculnya berbagai perilaku menyimpang pada anak dan dewasa tidak terlepas dari input informasi yang mereka terima dalam interaksinya dengan lingkungan.

Dance (dalam Jalaluddin Rahmat, 2005), mengartikan komunikasi dalam kerangka psikologi behaviorisme sebagai usaha menimbulkan respon melalui lambanglambang verbal, ketika lambang lambang verbal tersebut bertindak sebagai stimuli. ${ }^{8}$ Secara luas, Psikologi mendefinikan komunikasi sebagai penyampaian energi dari alatalat indera ke otak, pada peristiwa penerimaan dan pengolahan informasi, pada proses saling pengaruh diantara berbagai sistem dalam diri organisme dan diantara organisme. ${ }^{9}$

Studi pendahuluan yang dilakukan peneliti pada anak-anak dan orang tua di kabupaten Ponorogo, ditemukan bahwa intensitas anak-anak usia SD, SMP, dan SMA lebih banyak menghabiskan waktu mereka untuk bermain game dan berselancar di dunia maya dibanding dengan berinteraksi dengan orang tua, hal ini juga dibenarkan oleh para orang tua, mereka mengakui bahwa usai pulang sekolah, anak-anak lebih memilih bermain game dan berselancar di dunia maya. Para orang tua mengeluhkan perubabahan sikap anak-anak yang dirasa berlebihan dalam bermain HP, anak-anak menjadi sulit diatur, bersikap temperamen, bahkan cenderung diam dan enggan berkomunikasi dengan orang tua. ${ }^{10}$

Tidak hanya pada anak-anak, bermain game dan having fun di dunia maya juga dilakukan oleh orang dewasa (red. individu yang telah berkeluarga). ${ }^{11}$ Dalam kadar

${ }^{6}$ Irwan Kustiawan. Eksploritasi Antarmuka Grafis Pemakaian Tkinter Pada Lingkungan Bahasa Pyton. Skripsi. Fakultas Teknik UNPAS, 2017.

7 https://www.jpnn.com/news/hasil-survei-gadget-pemicu-perceraian?page=2. Diakses pada tanggal 10 Agustus 2019.

8 Jalaludin Rahmat. Psikologi Komunikasi. Bandung: Remaja Rosda Karya, 2005, 13

${ }^{9}$ Ibid.

${ }^{10}$ Hasil wawancara dengan Ibu-ibu peserta penyuluhan BKR Dsn. Bungu Desa Bungkal, 04 Agustus 2019. Pernyataan serupa juga dinyatakan oleh Wali Murid TK Dharma Wanita Ds. Jambon, Observasi dan wawancara dilakukan saat penyuluhan dan audiensi Guru-Wali murid pada tanggal 25 Juli 2019.

${ }^{11}$ Hasil wawancara dengan Ibu-ibu peserta penyuluhan BKR Dsn. Bungu Desa Bungkal, 04 Agustus 2019. 
tertentu, hal ini merupakan aktivitas yang wajar, akan tetapi jika hal ini dilakukan secara intensif, maka tentunya akan mempengaruhi perubahan pola-pola interaksi dalam keluarga. Perubahan ini mereduksi kualitas dan efektivitas komunikasi dalam keluarga, baik komunikasi antarpasangan maupun komunikasi antara orang tua dan anak. Disisi lain, sebagaimana kita fahami bersama, komunikasi yang efektif merupakan fondasi keharmonisan keluarga, sebaliknya komunikasi yang patologis hanya akan mengikis keberfungsian keluarga.

Secara teori, pola komunikasi keluarga menentukan kualitas kehidupan keluarga secara keseluruhan. Pembahasan tentang komunikasi keluarga sering didiskusikan bersamaan dengan konflik keluarga. Konflik keluarga merupakan manifestasi dari pola komunikasi sebuah keluarga. ${ }^{12}$ Tidak berlebihan jika dikatakan bahwa "Communications is The essence of Life", karena hanya dengan komunikasi yang baik tatanan kehidupan keluarga dapat berjalan dengan baik, begitupun sebaliknya. Maka berdasarkan paparan fenomena tersebut, penelitian ini mencoba memetakkan secara rinci pergeseran pola komunikasi keluarga sebagai dampak langsung dari adanya interaksi antara manusia dengan komputer (Red. Internet). Dengan mengetahui pemetaan ini, maka harapan pemerintah untuk memfokuskan pembangunan pada peningkatan kualitas SDM dapat diwujudkan.

\section{POLA KOMUNIKASI KELUARGA}

Kajian tentang komunikasi keluarga telah menjadi bidang khusus dalam disiplin ilmu komunikasi, hal ini diprakarsai oleh dua disertasi yang ditulis oleh Fitzpatrick dan Rogers. ${ }^{13}$ Dance (dalam Jalaluddin Rahmat, 2005), mengartikan komunikasi dalam kerangka psikologi behaviorisme sebagai usaha menimbulkan respon melalui lambang-lambang verbal, ketika lambang-lambang verbal tersebut bertindak sebagai stimuli. ${ }^{14}$ Secara luas, Psikologi mendefinikan komunikasi sebagai penyampaian energi dari alat-alat indera ke otak, pada peristiwa penerimaan dan pengolahan informasi, pada proses saling pengaruh diantara berbagai sistem dalam diri organisme dan diantara organisme. ${ }^{15}$

Menurut Keating et al., pola komunikasi keluarga diartikan sebagai suatu kerangka kerja yang berfokus pada cara individu dalam mengenali gaya komunikasi mereka dengan anggota keluarga yang lain. Sementara itu, Fitzpatrick dan Richie mendefinisikan pola komunikasi keluarga sebagai struktur keluarga dalam melakukan interaksi satu sama lain. ${ }^{16}$

12 Allan Sillars, et al. Communication, Conflict, And The Quality Of Family Relatioships. Handbook of Family Communications. Edited By: Anita L. Vangelisty. NJ: Lawrence Erlbaum Associates Publisher, 2004. P. 413-418.

${ }^{13}$ Frank D. Fincham. "Communication in Marriage". Hand bobok of Family Communication. Edited By Anita L. Vangelisty. NJ: Lawrence Erlbaum Associates Publisher, 2004. P. 83.

14 Jalaludin Rahmat. Psikologi Komunikasi. Bandung: Remaja Rosda Karya, 2005, 13

${ }^{15} \mathrm{Ibid}$.

16 Patricia Dyess, "Family Commuication Pattern and Power Theory". Integrated Studies. 101, 2017. Project submitted in partial fulfillment of the Requirements for the Bachelor of Integrated Studies Degree, Murray State's Digital Commons of Murray State University. Diakses dari 
Konsep pola komunikasi keluarga menekankan pada dua jenis orientasi dalam fungsi komunikasi keluarga; yakni orientasi percakapan dan orientasi kesesuaian. Pada orientasi percakapan, digambarkan bagaimana masing-masing anggoa keluarga menunjukkan keterbukaan dan minatnya dalam membicarakan topik/permasalahan tertentu. Keluarga dengan orientasi percakapan yang tinggi (red. baik) akan menunjukkan minat dan keterbukaan yang luas dalam menyampaikan pendapat dan perasaan. Sebaliknya, keluarga dengan orientasi percakapan rendah memiliki lebih sedikit topik percakapan serta menunjukkan rasa kurang nyaman dalam menyampaikan berbagai informasi pribadi. ${ }^{17}$

Orientasi kesesuaian menekankan pada anggota keluarga dengan cara menempatkan berbagai tekanan pada kepatuhan yang bertujuan untuk menghindari konflik. Keluarga dengan orientasi kesesuaian yang tinggi (red. baik) akan menunjukkan kecenderungan menghindari konflik dan menekankan keharmonisan, demikian juga sebaliknya, keluarga dengan orientasi kesesuaian rendah memiliki kecenderungan untuk menunjukkan individualitas mereka serta lebih mudah mengekspresikan ketidaksepahamannya dengan anggota keluarga yang lain. ${ }^{18}$

Sebagai aktivitas sosial, komunikasi lazimnya terjadi ketika manusia berinteraksi dengan manusia yang lain. Kohler menyatakan bahwa komunikasi yang efektif sangat penting dalam sebuah organisasi, tidak terkecuali dalam keluarga. Menurut Tubbs dan Moss, dalam bukunya Jalaluddin Rahmat tahun 2005, menyatakan bahwa komunikasi yang efektif diindikasikan dengan terbentuknya 5 hal yaitu: pengertian, kesenangan, mempengaruhi perubahan sikap (positif), hubungan sosial yang baik, dan adanya tindakan. ${ }^{19}$ Kualitas komunikasi dalam keluarga merupakan salah satu indikator penentu keberfungsian keluarga. Diantara delapan fungsi keluarga, komunikasi menempati peran sentral dalam menentukan arah perkembangan keluarga menuju keluarga sehat dan bahagia. ${ }^{20}$

Pola komunikasi dalam sebuah keluarga mencerminkan kondisi psikologis masing-masing anggota keluarga. Kualitas komunikasi, baik verbal maupun non-verbal sangat menentukan perilaku individu dalam sistem keluarga. Dengan demikian, tidak berlebihan jika dikataka`n bahwa perilaku yang patologik lahir dari pola komunikasi keluarga yang patologis. Jika dirunut lebih jauh, pola komunikasi dalam keluarga muncul dari proses keluarga menciptakan dan berbagi realitas sosial, kongkritnya pola ini muncul dari pesan verbal dan nonverbal yang diberikan secara timbal balik, berulang dan dapat diprediksi dalam hubungan keluarga; pola interaksi ini dapat diubah oleh kekuatan dalam sistem keluarga itu sendiri.

https://digitalcommons.murraystate.edu/bis437/101?utm_source=digitalcommons.murraystate.edu \%2Fbis437\%2F101\&utm_medium=PDF\&utm_campaign=PDFCoverPages

17 Ibid., 7.

18 Ibid.

19 Jalaluddin Rahmat.. Psikologi Komunikasi.......hal 23.

${ }^{20}$ Anita L. Vangelisti. Handbook of Family Communication. NJ: Lawrence Elbaum Associates Publishers. 2004. P. 53. 
Komunikasi keluarga berbeda dengan komunikasi antarkelompok biasa. Karena setiap anggota keluarga memiliki pola komunikasi yang berbeda, perbedaan ini dipengaruhi oleh beberapa faktor diantaranya adalah sikap orang tua. Sikap orang tua berhubungan dengan afeksi dan dominasi. Setidaknya terdapat empat pola interaksi keluarga; pertama, interaksi suami terhadap istri; kedua, interaksi antara ibu dan anak; ketiga, interaksi antara ayah dan anak; dan keempat, interaksi tiga arah yang mencakup ibu, ayah, dan anak-anak. Dengan demikian, secara khusus, proses koordinasi sebagaimana interaksi manusia pada umumnya dan komunikasi keluarga pada khususnya, akan menciptakan satu realitas sosial yang baru, yang tentunya akan sangat berpengaruh terhadap sikap dan perilaku masing-masing individu sebagai subsistem dalam keluarga.

\section{HUMAN COMPUTER INTERACTION (HCI)}

Interaksi manusia dalam kehidupan sehari-harinya berperan besar dalam membentuk pola pikir tentang suatu informasi. Di dalam proses kegiatan sehari-hari yang mungkin tidak sepenuhnya kita sadari, pada dasarnya telah memberikan input sensorik yang akan disimpan dalam ingatan kita, termasuk interaksi manusia dengan teknologi. Pada dasarnya, tujuan dari interaksi manusia dan komputer adalah untuk menghasilkan sistem yang bermanfaat (usable) dan aman (safe), akan tetapi tampaknya hal ini masih menjadi "pekerjaan rumah" kita bersama. Sistem yang dimaksudkan untuk mengembangkan dan meningkatkan keamanan (safety), utilitas (utility), ketergunaan (usability), efektifitas (efectiveness) dan efisiensinya (efficiency) masih menyisakan kekhawatiran di kalangan sejumlah masyarakat, khususnya keluarga. Di sini tentunya kita tidaklah hendak "mengkambing hitamkan" teknologi, karena hal ini merupakan keniscayaan sebagai hasil dari perkembangan peradaban umat manusia, akan tetapi yang perlu kita garisbawahi adalah aspek human, yakni manusia sebagai pengguna aktif teknologi.

Tidak dapat dihindari, bahwa berbagai kemudahan yang ditawarkan oleh perkembangan teknologi turut menggeser pola-pola dalam sistem/tatanan kehidupan masyarakat sehari-hari, tak terkecuali adalah sistem kehidupan keluarga. Interaksi keluarga dengan perangkat teknologi (saat didominasi oleh gadget) yang semakin intensif adalah bukti nyata perubahan pola dalam sistem kehidupan mereka. Hal ini merupakan suatu yang wajar dan lazim terjadi, namun jika dihubungkan dengan aspek psikologis, khususnya dalam pembahasan psikologi keluarga dan psikologi komunikasi, maka fenomena ini menjadi isu yang cukup menarik untuk dikaji, di samping juga harus mendapatkan perhatian. Hal didasarkan pada indikasi adanya perubahan perilaku -khususnya perilaku komunikasi- dalam keluarga.

Dalam proses komunikasi, yang mencakup bagaimana keluarga menyatakan perasaan serta pikirannya untuk pengembangan dan pemeliharaan pola hubungan atas dasar ikatan batin dalam keluarga, juga melibatkan pengembangan dan pemeliharaan perasaan antarpribadi (interpersonal system), maka dapat dikatakan bahwa interaksi manusia-komputer pada keluarga di Kabupaten Ponorogo cukup intensif. Hal ini dapat 
dilihat dari pola komunikasi yang turut berubah sesuai dengan perubahan mekanisme hubungan antarpribadi dalam keluarga.'

Tidak dapat dipungkiri, dan tentunya kita harus "fair" dalam melihat fenomena ini, yakni jika mengacu pada tujuan dari interaksi manusia dan komputer yakni usable, safe, efectiveness, dan efficiency, maka interaksi manusia-komputer pada keluarga tidak hanya memberikan dampak negative (perubahan pola komunikasi), akan tetapi pada aspek lain dapat dikatatakan cukup efektif dalam memberikan kemudahan pada proses komunikasi secara umum. Keluarga di Kabupaten Ponorogo mengakui, hadirnya teknologi memberikan manfaat terbesar dalam hal kemudahan komunikasi dan pemerolehan informasi, ${ }^{21}$ hal ini tentunya sesuai dengan tujuan dikembangkannyan sistem komputer itu sendiri, yakni pada aspek usable dan safe. Adapun untuk effectiveness dan efficiency sangatlah bergantung pada faktor human sebagai pengguna dari perangkat tersebut. Konkretnya adalah, semakin bijak dan cerdas individu dalam memanfaatkan media tersebut, maka akan banyak memberikan manfaat bagi kehidupan, demikian juga sebaliknya.

Intensitas interaksi manusia-komputer pada keluarga jika ditinjau dari aspek komponen dasar yang menyusunnya, dapat diuraikan dalam tiga komponen penting, yakni: Pertama, Manusia. Sebagai pengguna/user yang memakai komputer atau sistem tersebut, manusia memiliki karakter dan perilaku yang berbeda-beda dengan kebutuhannnya dalam menggunakan komputer. Hal ini didasarkan pada beberapa faktor, diantaranya adalah faktor pendidikan, pekerjaan, dan ekonomi. Dilihat dari faktor pendidikan misalnya, keluarga dengan tingkat pendidikan lebih tinggi memiliki intensitas penggunaan teknologi yang lebih intensif dan beragam dibanding keluarga dengan tingkat pendidikan yang lebih rendah. Hal ini tidak hanya dilihat dari waktu penggunaan, akan tetapi juga ragam aplikasi dan informasi yang diakses. Kedua, Komputer. Sebagai salah satu perangkat teknologi yang digunakan masyarakat, akan tetapi saat ini masyarakat lebih dominan menggunakan perangkat Mobile, khususnya gadget. Dengan gadget, masyarakat mendapatkan kemudahan dalam mengakses apapun, khususnya berkomunikasi. Secara psikologis, perangkat kasar (hardware) pada era kekinian didesain sedemikian simpel dan canggih. Bisa dibayangkan, beragam perangkat kini dijadikan dalam satu genggaman saja, dan hal ini akan terus dikembangkan oleh industri teknologi, tidak lain bertujuan untuk mempermudah aktivitas manusia dalam kehidupan sehari-hari. Ketiga, Interface. Interaksi antara manusia dan komputer melalui antarmuka yang ada di dalam sistem komputer yang memungkinkan manusia berhubungan dengan komputer.

\section{HCI DAN PERGESERAN POLA KOMUNIKASI KELUARGA}

Interaksi manusia dengan beragam perangkat teknologi berimplikasi baik positif maupun negatif dalam kehidupannya. Dalam perspektif teori system keluarga misalnya, keluarga dipandang sebagai satu unit emosional yang saling terkait dan terhubung satu sama lain. Keterkaitan ini akan membentuk satu ritme saling

${ }^{21}$ Hasil wawancara, 20 April 2020. 
ketergantungan antaranggota keluarga, dalam konteks ini seseorang akan menjalani hidup mereka sebagai bagian dari kelompok, bukan lagi sebagai individu.

Sistem keluarga mulai terbentuk ketika dua atau lebih individu telah bersatu dalam suatu hubungan yang mengikat, bermula dari sinilah maka semua aktivitas perilaku masing-masing individu akan saling mempengaruh satu sama lain. Sistem keluarga memandang bahwa keluarga tidak hanya sekumpulan individu yang tinggal Bersama, akan tetapi merupakan system social yang alamiah dengan segala kepemilikannya yang melibatkan sejumlah aturan main, beberapa peran, struktur kekuasaan, pola komunikasi, serta cara negosiasi dan pemecahan masalah.

Jika dikaitkan dengan teori system keluarga, maka perubahan yang terjadi pada keluarga di Kabupaten Ponorogo merupakan dampak sistemik atas perubahan social secara umum. Perubahan ini, khususnya perubahan pola komunikasi, banyak dipengaruh oleh derasnya informasi yang diperoleh secara online. Dari sinilah sebuah interaksi menjadi lebih kompleks, karena tidak hanya dilakukan secara nyata (tatap muka), tetapi juga secara maya. Di sisi lain, telah jamak diketahui bahwa apa yang disuguhkan dalam dunia maya, media sosial misalnya, tidaklah menunjukkan realitas kehidupan yang sebenarnya. Secara psikologis hal semacam ini juga akan berpengaruh terhadap sistem komunikasi keluarga, dimana individu akan cenderung "terobsesi" untuk menunjukkan eksistensinya secara maya dan abai dengan realitas kehidupan yang nyata.

Komunikasi berfungsi sebagai inti dari suatu sistem, karena pada dasarnya suatu hubungan dibentuk, dipelihara, dan diubah melalui interaksi antar individu. Dengan demikian, untuk menciptakan sebuah sistem yang baik, masing-masing individu perlu memahami perilakunya sendiri sebelum memahami perilaku orang lain sebagai hal yang saling terkait, keterkaitan ini akan membentuk satu "ritme" saling ketergantungan antaranggota keluarga, dengan tetap fokus pada sistem keluarga, tanpa menjadikan "masalah" sebagai kesalahan salah satu anggota saja. Dalam konteks komunikasi keluarga, interaksi manusia-komputer tidak hanya berdampak pada perubahan komunikasi antarpasangan, tetapi juga komunikasi antara orang tua dan anak. penggunaan internet dengan intensitas tertentu pada anak-anak, dapat merubah pola perilaku anak menjadi lebih temperamen, termasuk dalam hal komunikasi. Anak-anak lebih tertarik bermain di dunia maya daripada berkomunikasi langsung dengan orangtua.

Perubahan pola ini telah mereduksi unsur-unsur dalam sistem keberfungsian keluarga, yakni berkurangnya ketergantungan/interdependensi anak terhadap orang tua, karena anak lebih memilih untuk berinteraksi dengan teknologi dibanding dengan orang tuanya. Hilangnya interdependensi tersebut secara tidak langsung akan mengikis keseimbangan dalam keluarga, serta berpotensi untuk memunculkan problem-problem baru yang bersifat sistemik. Munculnya saling ketergantungan ini merupakan pusat dari suatu sistem, yang saling berhubungan dan membentuk keseluruhan, sehingga perubahan pada satu bagian akan berpengaruh terhadap perubahan yang lain. 
Berkurangnya interdependensi, tidak hanya terjadi pada anak-anak terhadap orang tua, akan tetapi juga terjadi pada pasangan suami istri.

Hubungan keluarga yang baik dan bermakna dibangun di atas fondasi komunikasi yang kuat. Komunikasi yang efektif dalam keluarga akan menciptakan dan menjaga ikatan keluarga dengan baik. Komunikasi adalah cara individu dalam mengirim dan menerima pesan, yakni dengan cara yang menciptakan pemahaman. Sebagian besar komunikasi bersifat nonverbal yang mencakup bahasa tubuh, ekspresi wajah, dan nada suara. Hal tersebut akan memberi orang lain lebih banyak informasi dari pada apa yang dikatakan.22

Selain aspek interdependensi keluarga, interaksi manusia-komputer juga berpengaruh terhadap wholeness (keutuhan) keluarga, hal ini ditandai dengan berkurangnya waktu keluarga untuk berkomunikasi secara langsung, baik antarpasangan maupun antara orang dan anak. Mengingat bahwa sistem keluarga memberikan ciri khas yang terbentuk dari integrasi antara karakteristik individu dan interaksi yang terjadi dalam keluarga. Ciri khas ini kemudian dipahami oleh orang luar sebagai "ciri khas keluarga" secara keseluruhan. Wholeness mencakup keseluruhan unsur dalam keluarga, diantaranya fisik, mental, spirit, kesadaran, keterhubungan, pembelajaran, serta saling berbagi. Interaksi manusia-komputer pada keluarga di Kabupaten Ponorogo mulai tampak mendistraksi sistem "keutuhan" keluarga, meski hal ini tidak selalu berdampak negatif, akan tetapi tetaplah harus menjadi perhatian seluruh anggota keluarga guna mengantisipasi munculnya dampak negatif.

Secara psikologis, perubahan perilaku pada anggota keluarga akibat interaksi mereka dengan teknologi sesuai dengan kecenderungan alami manusia, dimana individu memiliki rasa ingin tahu yang tinggi tentang sesuatu yang baru, keinginan untuk menunjukkan identitas diri yang otonom di tengah-tengah masyarakat -termasuk dunia maya-, keinginan untuk mengeksplorasi dunia mereka (khususnya pada anak dan remaja), dan lain sebagainya. Meskipun secara kognitif, orang tua merupakan individu dewasa yang telah mampu berfikir secara abstrak, membuat formasi konsep, yang dilakukan dengan proses mengingat (remembering), memahami (understanding), menerapkan (applying), dan menganalisis (analizing), akan tetapi kemampuan tersebut dapat berfungsi optimal jika didukung oleh faktor intern dan ekstern yang memadai.

Karakteristik sistem keluarga yang ke tiga adalah pola/regulasi diri. Setiap anggota keluarga belajar untuk mengkoordinasikan tindakan mereka dalam sistem keluarga, menciptakan pola bersama yang tidak dapat dibuat secara individu. Meskipun koordinasi tindakan bervariasi di seluruh sistem keluarga, akan tetapi setiap sistem keluarga mengembangkan pola komunikasi tertentu yang akan membentuk sebuah tujuan hidup. Masing-masing anggota keluarga belajar untuk hidup dalam secara timbal balik, berpola, dan berulang. Dari sini dapat dilihat bahwa pola interaksi dapat memberikan satu gambaran/lensa untuk menilai bagaimana perilaku komunikasi dalam suatu sistem keluarga.

${ }^{22}$ Sandra J. Bailey. Positive Family Communications: A self learning Resources from MSU Extension (2009), P. 1 
Sebagai keluarga Jawa yang tinggal di wilayah kota kecil dan pedesaan, keluarga di Kabupaten Ponorogo pada umumnya masih menjunjung tinggi tradisi dan karakter keluarga yang menjunjung tinggi kebersamaan, etika, moral serta nilai-nilai sosial lainnya. Interaksi manusia-komputer mengisyaratkan munculnya fenomena baru yang berpotensi merubah pola yang telah ada sebelumnya, di sini penulis tidak bermaksud anti perubahan, akan tetapi bagaimana fenomena baru tersebut tidak menghilangkan pola-pola lama yang sarat dengan nilai-nilai luhur, lebih-lebih jika harus terganti dengan pola baru yang justru merendahkan martabat manusia. Adapun kaitannya dengan regulasi diri adalah bahwa untuk mencapai keseimbangan dalam kehidupan keluarga, seluruh anggota keluarga hendaknya memiliki kemampuan dalam mengelola sistem yang kompleks dengan seperangkat aturan serta tren yang sedang berkembang. Dengan demikian, apapun perubahan yang terjadi, keluarga tetap mampu beradaptasi secara fleksibel tanpa meninggalkan nilai-nilai luhur yang ada.

Karakteristik sistem keluarga yang keempat adalah kompleksitas interaktif. Sebagaimana dipaparkan sebelumnya bahwa teori sistem mengisyaratkan hubungan sebab akibat dari perilaku tertentu, serta mengibaratkan bahwa sebab akibat dapat dipertukarkan. Dengan kata lain, perilaku yang terjadi hari ini adalah respons atas tindakan yang telah terjadi sebelumnya sekaligus sebagai stimulus untuk tindakan di masa yang akan datang. Demikian halnya dengan kompleksitas interaktif, ia menekankan bahwa setiap tindakan memicu munculnya perilaku baru serta menanggapi perilaku sebelumnya, menjadikan upaya untuk menetapkan sebab dan akibat menjadi sia-sia. Sebagai contoh kongkret misalnya, jika ada seorang anak yang kecanduan gadget, maka penyebabnya bukan hanya si anak, akan tetapi juga akibat dari perilaku orang tua yang permisif misalnya, atau tidak memberikan teladan bagaimana menggunakan teknologi secara bijak. Inilah yang disebut sebagai kompleksitas interaktif dalam teori sistem.

Karakteristik kelima adalah keterbukaan/openness. Karakteristik ini menekankan bahwa tidak ada individu yang tidak terkait satu sama lain, maka tidak ada keluarga yang tidak terikat. Sistem manusia yang mencakup individu, keluarga, komunitas, dan budaya akan membentuk lapisan yang saling terkait, dan hal tersebut perlu dipertukarkan dengan orang lain agar tetap berfungsi secara fisik dan psikologis. Setiap keluarga beroperasi dalam sistem yang lebih besar, yang mencakup sistem hukum, pendidikan, politik, kesehatan, dan ekonomi, serta sistem dalam keluarga besar dan persahabatan. Pada keluarga di Kabupaten Ponorogo, keterikatan satu sama lain tidak hanya melibatkan komunitas di sekitar, namun juga komunitas dunia maya, bahkan sangat memungkinkan terhadap orang-orang yang belum pernah mereka jumpai sebelumnya. Hal inilah yang menjadikan lapisan komunitas dalam interaksi manusia semakin meluas, bahkan bisa jadi keterkaitan secara maya lebih kuat dibanding keterkaitan secara nyata.

Karakretistik keenam adalah hubungan yang kompleks. Sistem yang tertanam dalam sistem akan menciptakan serangkaian struktur dan pola interaksi yang sangat kompleks, dan hanya dapat dipahami dalam kaitannya satu sama lain. Dalam konteks 
komunikasi keluarga di Kabupaten Ponorogo, kehadiran teknologi belum berdampak pada perubahan struktur yang sangat kompleks, mengingat penggunaan teknologi masih sebatas pada akses media sosial dan game, berbeda dengan masyarakat perkotaan yang memanfaatkan teknologi untuk urusan yang lebih kompleks.

Karakteristik sistem yang terakhir adalah kesamaan/Equifinality. Sistem keluarga yang adaptif dan terbuka cenderung menunjukkan kesetaraan, yang berarti bahwa "keadaan akhir tertentu dapat dicapai dengan cara yang berbeda dan dari titik awal yang berbeda"23, dalam sistem keluarga ini diyakini bahwa terdapat banyak cara untuk mencapai hasil yang sama. Berdasarkan teori sistem, kesamaan menjadi komponen penting yang harus dikomunikasikan dalam keluarga sejak awal dibentuknya sistem keluarga, misalnya saja terkait pembagian peran dalam rumah tangga, dengan dikomunikasikannya pembagian peran dalam rumah tangga akan menciptakan rasa "setara" tanpa ada yang merasa "tereksploitasi" dalam menjalankan peran-peran rumah tangga yang kompleks.

Dalam konteks keluarga di kabupaten Ponorogo, berdasarkan hasil penggalian data pada masyarakat di kabupaten Ponorogo, ditemukan bahwa karakteristik "kesamaan" dalam keluarga sudah mulai terbentuk dengan baik. Hal ini dinyatakan oleh informan bahwa dalam pasangan tidak lagi mempermasalahkan pembagian peranperan dalam keluarga, sekalipun pada keluarga dengan istri bekerja. Mereka menyadari bahwa era saat ini "menuntut" peran perempuan tidak hanya terbatas pada sektor domestik rumah tangga, tetapi juga turut serta membantu suami dalam pemenuhan nafkah keluarga. Peran ini tidak selalu identik dengan perempuan bekerja di luar rumah, tetapi juga bisa dilakukan dengan usaha mandiri dari rumah. Dengan demikian tugas utama sebagai ibu rumah tangga tidak terabaikan. ${ }^{24}$

Paparan diatas menjelaskan bahwa interaksi manusia-komputer telah berdampak sistemik pada perubahan pola komunikasi keluarga. Dengan demikian perlu diupayakan untuk membangun fondasi komunikasi yang kuat dalam keluarga. Upaya membangun pola komunikasi yang baik ini bukanlah tanggung jawab salah satu anggota keluarga, melainkan tanggung jawab bersama seluruh anggota keluarga sebagai satu kesatuan sistem. Sebagai instrumen kunci kebahagiaan keluarga, upaya membangun dan mempertahankan pola komunikasi yang sehat merupakan keniscayaan yang semestinya terus diupayakan, meski kehadiran teknologi saat ini telah merubah beberapa pola yang ada, akan tetapi dengan komitmen dari seluruh anggota keluarga -khususnya pasangan- komunikasi yang efektif tetap dapat diwujudkan.

Jika dilihat dari teori sistem, keberadaan keluarga sebagai unit terkecil dari masyarakat memiliki peran yang sangat sentral dalam pembentukan SDM masyarakat yang berkualitas dan unggul. Masyarakat yang sejahtera dan sehat adalah akumulasi dari unit-unit keluarga yang sejahtera dan sehat pula, demikian halnya sebaliknya. Pola

\footnotetext{
${ }^{23}$ Littlejohn, 2002, hlm. 41, dalam Kathleen M. Galvin, et al. Family Communication: Cohesion And Change. NY: Roudledge, 2016. P. 78.

24 Hasil wawancara dengan 35 Informan yang tersebar pada 15 Kecamatan di Kabupaten Ponorogo pada bulan April tahun 2020.
} 
interaksi yang semakin kompleks telah berimplikasi pada terbentuknya sistem emosional yang juga jauh lebih kompleks, sama halnya dengan sistem sosial di masyarakat, sebagaimana disebutkan bahwa keluarga mewakili unit terkecil yang sangat penting dalam pranata sosial, maka semua pergeseran yang merubah dan mereduksi tatanan sistem keluarga haruslah disikapi dengan bijaksana, sehingga tidak berdampak negatif terhadap keluarga.

Dalam teori sistem, dijelaskan dua orientasi komunikasi keluarga, yakni orientasi konformitas atau orientasi kesesuaian yang mengacu pada sejauh mana keluarga menciptakan iklim-iklim yang menekankan pada homogenitas sikap, nilai, dan kepercayaan; dan orientasi percakapan yakni sejauh mana keluarga menciptakan iklim dimana semua anggota keluarga didorong untuk berpartisipasi secara bebas dalam interaksi tentang beragam topik.

Melihat dua dimensi komunikasi tersebut, dapat dipahami bahwa upaya keluarga di Kabupaten Ponorogo dalam meminimalisir dampak negatif teknologi didasarkan pada model "internal" masing-masing keluarga dalam berkomunikasi dan berinteraksi. Skema ini merupakan struktur pengetahuan yang mewakili kondisi internal keluarga dan memberikan dasar untuk menafsirkan apa yang dikatakan dan dilakukan oleh anggota keluarga. Setiap skema memiliki seperangkat keyakinan, sikap, dan filosofi tersendiri tentang kehidupan keluarga yang dicirikan dengan perilaku komunikasi yang sangat spesifik. Skema keluarga pegawai tentu berbeda dengan skema keluarga pedagang, petani, Kyai, dan lain sebagainya. Atau skema keluarga konvensional juga berbeda dengan skema keluarga modern, dan seterusnya.

\section{KESIMPULAN}

Kajian tentang komunikasi keluarga pada dasarnya telah banyak dilakukan oleh para akademisi, dalam bidang psikologi misalnya, akan tetapi sampai saat ini, kajian tentang komunikasi keluarga masih menjadi tema yang menarik untuk dibahas, mengingat pembahasan tentang komunikasi bersifat sangat dinamis seiring dengan perkembangan zaman. Dinamika ini tentunya menyisakan jejak perubahan pola-pola tertentu yang harus disikapi secara bijak oleh masing-masing individu dalam sebuah sistem keluarga.

Intensitas interaksi antara manusia dengan teknologi telah menggeser sebagian pola kehidupan keluarga, salah satunya adalah pola komunikasi keluarga. Pergeseran ini terjadi secara sistemik, menjangkau seluruh elemen anggota keluarga, mulai dari anak-anak, orang tua, serta anggota keluarga yang lebih luas. Sebagai objek utama dalam pembahasan ini, interaksi manusia-komputer pada keluarga di Kabupaten Ponorogo memberikan dampak yang cukup efektif baik, khususnya dalam aspek kemudahan berkomunikasi dan mengakses informasi.

Ditinjau dari tujuh karakteristik dalam teori sistem, intensitas penggunaan teknologi pada keluarga di kabupaten Ponorogo, tidak ditemukan adanya dampak perubahan system komunikasi keluarga secara signifikan. Hal ini dapat diketahui dari 
beberapa karakteristik sistem keluarga yang masih berfungsi dengan baik. misalnya adalah hubungan yang kompleks, hal ini dihubungkan dengan kecenderungan penggunaan teknologi pada keluarga di Kabupaten Ponorogo masih sebatas pada akses media sosial dan game, berbeda dengan masyarakat perkotaan yang memanfaatkan teknologi untuk kepentingan yang lebih kompleks.

Meskipun secara system tidak menggeser pola-pola yang lama secara ekstrem, akan tetapi keluarga di kabupaten ponorogo mulai merasakan adanya perubahan pada aspek-aspek tertentu kehidupan mereka, khususnya adalah munculnya konflik antarpasangan yang berakar dari masalah penggunaan media social. Demikian halnya perubahan pada perilaku anak-anak yang ditandai dengan meningkatnya sikap temperamen dan egosentris pada anak.

Hasil penelitian ini, diharapkan dapat menjawab dampak pola interaksi yang semakin kompleks, terbentuknya sistem emosional yang juga jauh lebih kompleks, sehingga keberadaan keluarga yang mewakili unit terkecil dalam pranata sosial tetap tangguh dan seimbang dalam menghadapi semua pergeseran yang merubah dan mereduksi tatanan sistem keluarga modern.

Penelitian ini juga diharapkan dapat melengkapi kajian-kajian terdahulu yang telah dituangkan dalam buku-buku komunikasi dan psikologi yang mengambil fokus pada kajian keluarga, misalnya buku yang berjudul Family Communication: Cohesion and Change, ditulis oleh Kathleen M. Galvin dari Northwestern University, Dawn O. Braithwaite dari Northwestern University, dan Carma L. Bylund dari Northwestern University.

\section{DAFTAR RUJUKAN}

Abdullah, Amin. Menuju Keluarga Bahagia. Yogyakarta: PSW IAIN Yogyakarta- McGillICIHEP, 2002.

Afifi, Tamara D. et al. "The Chilling Effect and Family Secrets: Examining the Role of Self Protection, Other Protection, and Communication Efficacy". Human Communication Research, Volume 31, Issue 4, October 2005. https:/ / doi.org/10.1111/j.1468-2958.2005.tb00883.x

Atkinson, Rita L., dkk. Pengantar Psikologi Jilid 1. Jakarta: Erlangga, 1996.

Bailey, Sandra J. "Positive Family Communications". A self learning Resources from MSU Extension. 2009.

Barrier, Tonya. Human Computer Interaction Development and management. UK: Idea Group. Inc. 2002.

Bastaman, Hanna Jumhana, Integrasi Psikologi Dengan Islam Menuju Psikologi Islami. Yogyakarta: Pustaka Pelajar, 2001.

Berger, Peter \& H. Kellner. "Marriage and the Construction of Reality: An Exercise in the Microsociology of Knowledge". SAGE Journals Vol. 12 Issue 26.

Born, dkk. Perbedaan ciri-ciri psikologis antara laki-laki dan perempuan berdasarkan faktor ekologis dan budaya. Jurnal Intelektual Vol. 3 No. 2 Tahun 1987. 
Chalil, Mufidah. Psikologi Keluarga Islam Berwawasan Gender. Malang: UIN Maliki Press. 2013

Clark, Herbert H. Using Language. Cambridge: Cambridge University Press. 1996.

Effendy, Onong Uchyana. Ilmu Komunikasi: Teori dan Praktek. Bandung: Remaja Rosda Karya, 2007.

Fitzpatrick, Mary Anne. “Family Communication Patterns Theory: Observations on Its Development And Application". Journal of Family Communication, Vol. 4, Number 3\&4, 2004. DOI: 10.1080/15267431.2004.9670129. P. 172 - 173.

Galvin, Kathleen M. et al. Family Communication: Cohesion And Change. NY: Roudledge, 2016.

Gunarsa, Singgih D. Psikologi Praktis: Anak, Remaja dan Keluarga. Jakarta: PT. BPK Gunung Mulia. 2008.

Hawari, D. (2006). Marriage counseling (Konsultasi perkawinan). Jakarta: Fakultas Kedokteran, Universitas Indonesia.

Khairuddin, Sosiologi Keluarga. Yogyakarta: Liberty: 2008.

Klein, D. M. \& White, J. M. (1996). Family theories. London: Sage Publications

Kustiawan, Irwan. "Eksploritasi Antarmuka Grafis Pemakaian Tkinter Pada Lingkungan Bahasa Pyton". Skripsi. Bandung: Fakultas Teknik UNPAS, 2017.

Liddle, H. A., Santisteban, D. A., Levant, R. F., \& Bray, J. H. (2002). Family psychology. science-based interventions. Washington: APA.

Light, Janice. "Communication is The Essence of Human Life". Journal of Augmentative and Alternative Communication, Vol 13, 1997.

Megawangi, R., Zeitlin, M.F. \& Kramer, E.M. (1995). Psychological approaches to the family.

Mubarok, Achmad. Psikologi Keluarga Dari Keluarga Sakinah Hingga Keluarga Bangsa. Jakarta: Bina Reka Pariwara, 2005.

Quipper Campus, Tantangan Di Era Revolusi Industry 4.0 Bagi Perguruan Tinggi Di Indonesia. ttps://www.quipper.com/id/blog/quipper-campus/campusinfo/revolusi-industri-4-0/

Rahmat, Jalaludin. Psikologi Komunikasi. Bandung: Remaja Rosda Karya, 2005.

Sadarjoen, S.S. (2005). Konflik marital. Bandung: PT.Refika Aditama.

Santrock, J.W. Perkembangan Masa Hidup (Edisi ke-lima). Jakarta: Erlangga. 2002.

Santrock, J.W. Psychology (7th edition). Boston: McGraw-Hill. 2003

Sillars, Allan, et al. Communication, Conflict, And The Quality Of Family Relatioships. Handbook of Family Communications. Edited By: Anita L. Vangelisty. NJ: Lawrence Erlbaum Associates Publisher, 2004.

Sillars, Allan, et al. Communication, Conflict, And The Quality Of Family Relatioships. Handbook of Family Communications. Edited By: Anita L. Vangelisty. NJ: Lawrence Erlbaum Associates Publisher, 2004.

Suchman, Lucy. Plan and Situated Action; The Problem of Human-Machine Communication. NY, Cambridge: Cambridge University Press. 1999.

Walgito, B. (1984). Bimbingan dan konseling perkawinan. Yogyakarta: Andi Offset 
Vangelisti, Anita L. \& John P. Caughlin. "Revealing Family Secrets: The Influence of Topic, Function, and Relationships". Journal of Social and Personal Relationships. Vol. 14, Isuue 5, 1997. https:/ / doi.org/10.1177\%2F0265407597145006.

Vangelisti, Anita L. Handbook of Family Communication. NJ: Lawrence, 2004.

Wanzer, Melisa B. et al. "Family Communication: It's all relative from interpersonal communication; Building Rewarding Relationship". Book chapter; chapter 13, 2017.

Zarnaghash, Mina, et al., "The Relationship Between Family Communication Patterns and Mental Health". Procedia: Social and Behavioral Sciences. 2013. 